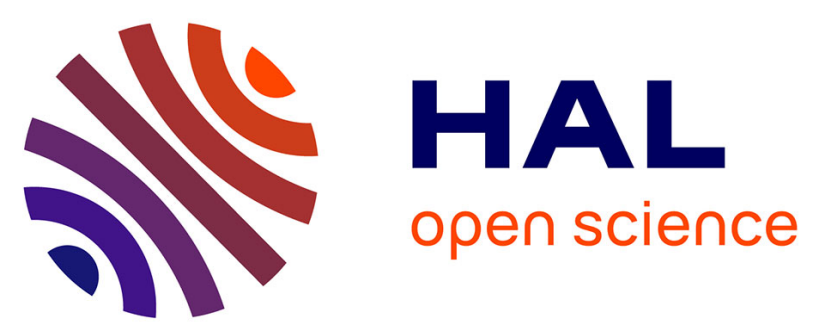

\title{
International Committee on Systematics of Prokaryotes Subcommittee on the Taxonomy of Rhizobia and Agrobacteria Minutes of the closed meeting by videoconference, 6 July 2020
}

Philippe de Lajudie, Seyed Abdollah Mousavi, J. Peter W. Peter W Young

\section{To cite this version:}

Philippe de Lajudie, Seyed Abdollah Mousavi, J. Peter W. Peter W Young. International Committee on Systematics of Prokaryotes Subcommittee on the Taxonomy of Rhizobia and Agrobacteria Minutes of the closed meeting by videoconference, 6 July 2020. International Journal of Systematic and Evolutionary Microbiology, 2021, 71 (5), 10.1099/ijsem.0.004784 . hal-03436268

\section{HAL Id: hal-03436268 \\ https://hal.inrae.fr/hal-03436268}

Submitted on 19 Nov 2021

HAL is a multi-disciplinary open access archive for the deposit and dissemination of scientific research documents, whether they are published or not. The documents may come from teaching and research institutions in France or abroad, or from public or private research centers.
L'archive ouverte pluridisciplinaire HAL, est destinée au dépôt et à la diffusion de documents scientifiques de niveau recherche, publiés ou non, émanant des établissements d'enseignement et de recherche français ou étrangers, des laboratoires publics ou privés. 


\title{
International Committee on Systematics of Prokaryotes Subcommittee on the Taxonomy of Rhizobia and Agrobacteria Minutes of the closed meeting by videoconference, 6 July 2020
}

\author{
Philippe de Lajudie', Seyed Abdollah Mousavi 2,3,* and J. Peter W. Young ${ }^{4}$
}

\section{MINUTE 1. CALL TO ORDER}

The annual Subcommittee meeting by videoconference was called to order by Peter Young at 11.00 UTC on 6 July 2020 .

\section{MINUTE 2. RECORD OF ATTENDANCE}

Present (22): J. Peter W. Young (University of York, UK, chairperson), Philippe de Lajudie (IRD, Montpellier, France, secretary), Mitchell Andrews (Lincoln University, Canterbury, New Zealand), Julie Ardley (Murdoch University, Perth, Australia), Bertrand Eardly (Penn State Berks College, Reading, PA, USA), Nemanja Kuzmanović (Julius Kühn-Institut, Braunschweig, Germany), Florent Lassalle (Imperial College, St Mary's Hospital, London, UK), Kristina Lindström and Seyed Abdollah Mousavi (University of Helsinki, Finland), Esperanza Martinez-Romero (UNAM, Cuernavaca, Mor., Mexico), Lionel Moulin (IRD, Montpellier, France), Xavier Nesme (INRA, University of Lyon I, Villeurbanne, France), Joanna Puławska (Research Institute of Horticulture, Skierniewice, Poland), Emma T. Steenkamp (University of Pretoria, South Africa), Tomasz Stępkowski (University of Life Sciences, Warsaw, Poland), Chang-Fu Tian (China Agricultural University, Beijing, China), Pablo Vinuesa (Centro de Ciencias Genómicas - UNAM, Cuernavaca, Mor., Mexico), Gehong Wei (Northwest A and F University, Yangling, Shaanxi, China), Anne Willems (University of Gent, Belgium) and Jerri Edson Zilli (Embrapa Agrobiologia, Seropédica, Rio de Janeiro, Brazil).

Apologies for absence (2): Alvaro Peix (Institute of Natural Resources and Agrobiology, Salamanca, Spain) and Ridha Mhamdi (Centre de Biotechnologie de Borj-Cédria, Hammam-lif, Tunisia).

\section{MINUTE 3. SUBCOMMITTEE PUBLICATIONS}

The minutes of our previous meeting (2019) have been published [1].

\section{MINUTE 4. MEMBERSHIP ISSUES}

4.1. As pointed out in the minutes of our last meeting, the Statutes of the International Committee on Systematics of Prokaryotes have been revised [2]. We considered carefully article 6 detailing rules on the organization and missions of subcommittees. According to these, regular members (those who are members of a society affiliated to the International Union of Microbiological Societies (IUMS) and having voting rights in the administrative workings of the Subcommittee) are: J. Peter W. Young (Microbiology Society), Seyed Abdollah Mousavi (Iranian Society of Microbiology, ISM), Bertrand Eardly (American Society for Microbiology), Florent Lassalle (Microbiology Society), Kristina Lindström (Biobioseura), Esperanza Martinez-Romero (Asociación Mexicana de Microbiologia), Alvaro Peix (Spanish Society for Microbiology), Chang-Fu Tian (Chinese Society for Microbiology), Gehong Wei (Chinese Society for Microbiology), Anne Willems (Microbiology Society, Belgian Society for Microbiology), Jerri Edson Zilli (Brazilian Society of Microbiology) and Emma T. Steenkamp (South African Society for Microbiology, SASM). Co-opted members are: Mitchell Andrews, Julie Ardley, Nemanja Kuzmanović, Philippe de Lajudie, Ridha Mhamdi, Lionel Moulin, Xavier Nesme, Joanna Puławska, Tomasz Stępkowski and Pablo Vinuesa.

4.2. Admissions, Resignations. Mitchell Andrews announced his need to withdraw from the Subcommittee due to recent job change and lack of time to contribute to the sub-committee's discussions anymore. The Subcommittee will miss him as a very useful and contributive member and, in the name of all members, we thank him for taking his commitment seriously and for all his contributions over the years - they have been genuinely important and much appreciated.

4.3. Chairperson and Secretary elections. Prof. J. Peter W. Young was reappointed as the Chairperson of the Subcommittee and Dr. Seyed Abdollah Mousavi (University of Helsinki, Finland) was appointed as Secretary to serve for a 3 year term starting on 1 September 2020. There was no

Author affiliations: 'IRD, University of Montpellier, CIRAD, INRAE, SupAgro, LSTM, Montpellier, France; ${ }^{2}$ Ecosystems and Environment Research Programme, University of Helsinki, Finland; ${ }^{3}$ Department of Biology, University of Turku, Finland; ${ }^{4}$ Department of Biology, University of York, York Y010 5DD, UK.

*Correspondence: Seyed Abdollah Mousavi, seyed.mousavi@helsinki.fi

Keywords: rhizobia; agrobacteria; International Subcommittee on Taxonomy.

$004784 \odot 2021$ The Authors 
Table 1. Novel taxa described since the last meeting of the Subcommittee

The names indicated in inverted commas have been proposed in effective publications, but have not yet been validated by publication in the IJSEM (do not figure in a validation list).

\begin{tabular}{|c|c|c|c|c|c|}
\hline $\begin{array}{l}\text { Species and nomenclatural type } \\
\text { strain }\end{array}$ & Origin & $\begin{array}{l}\text { T-strain Genome } \\
\text { NCBI assembly } \\
\text { (RefSeq) accession }\end{array}$ & $\begin{array}{l}\text { Symbiotic/ } \\
\text { pathogenic } \\
\text { genes }\end{array}$ & Planttests & Reference \\
\hline \multicolumn{6}{|l|}{ Agrobacterium } \\
\hline $\begin{array}{l}\text { Agrobacterium cavarae RZME10 }{ }^{\mathrm{T}} \\
\left(=\text { CECT } 9795^{\mathrm{T}}=\mathrm{LMG} 31257^{\mathrm{T}}\right)\end{array}$ & Zea mays L. root, Spain & GCF_004310285.1 & - & - & [20] \\
\hline $\begin{array}{l}\text { Agrobacterium fabacearum CNPSo } \\
675^{\mathrm{T}}\left(=\mathrm{UMR} 1457^{\mathrm{T}}=\mathrm{LMG} 31642^{\mathrm{T}}\right)\end{array}$ & $\begin{array}{l}\text { Nodules of soybean and common bean in } \\
\text { Brazil, Mexico, Ecuador and Mozambique }\end{array}$ & GCF_009649785.1 & vir & Nod- & [21] \\
\hline \multicolumn{6}{|l|}{ Allorhizobium } \\
\hline $\begin{array}{l}\text { 'Allorhizobium oryziradicis' comb. } \\
\text { nov. } \mathrm{N}^{\mathrm{T}}{ }^{\mathrm{T}}\left(=\mathrm{ACCC} 19962^{\mathrm{T}}=\mathrm{KCTC}\right. \\
\left.52413^{\mathrm{T}}\right)\end{array}$ & & GCF_001939045.1 & & & {$[11,22]$} \\
\hline $\begin{array}{l}\text { Allorhizobium taibaishanense comb. } \\
\text { nov. CCNWSX } 0483^{\mathrm{T}}(=\mathrm{DSM} \\
\left.100021^{\mathrm{T}}=\text { HAMBI } 3214^{\mathrm{T}}\right)\end{array}$ & & GCF_001938985.1 & & & [11] \\
\hline \multicolumn{6}{|l|}{ Bradyrhizobium } \\
\hline $\begin{array}{l}\text { Bradyrhizobium archetypum WSM } \\
1744^{\mathrm{T}}\left(=\text { CNPSo } 4013^{\mathrm{T}}=\mathrm{LMG}\right. \\
\left.31646^{\mathrm{T}}\right)\end{array}$ & $\begin{array}{c}\text { Root nodule of Muelleranthus trifoliolatus, } \\
\text { Western Australia }\end{array}$ & GCF_013114835.1 & $\operatorname{nod} A$, nifD, nifH & Nod+ & [23] \\
\hline $\begin{array}{l}\text { Bradyrhizobium australiense WSM } \\
1791^{\mathrm{T}}\left(=\text { CNPSo } 4014^{\mathrm{T}}=\mathrm{LMG}\right. \\
\left.31647^{\mathrm{T}}\right)\end{array}$ & $\begin{array}{c}\text { Root nodule of Indigofera sp., Western } \\
\text { Australia }\end{array}$ & GCF_013114825.1 & nodA, nifD, nifH & Nod+ & [23] \\
\hline $\begin{array}{l}\text { 'Bradyrhizobium campsiandrae' } \\
\text { UFLA01-1174 }{ }^{\mathrm{T}}(=\mathrm{INPA} \\
\left.394 \mathrm{~B}^{\mathrm{T}}=\mathrm{LMG} 10099^{\mathrm{T}}\right)\end{array}$ & $\begin{array}{l}\text { Root nodule of Campsiandra laurilifolia, } \\
\text { Amazon rain forest flooded area, Brazil }\end{array}$ & GCF_014529705.1 & nodA, nifD, nifH & Nod+ & [24] \\
\hline $\begin{array}{l}\text { Bradyrhizobium cosmicum } 58 \mathrm{S1}^{\mathrm{T}} \\
\left(=\mathrm{LMG} 31545^{\mathrm{T}}=\mathrm{HAMBI} 3725^{\mathrm{T}}\right)\end{array}$ & $\begin{array}{l}\text { Non-nodulating diazotroph originating from } \\
\text { soybean nodule, Canada }\end{array}$ & GCF_007290395.1 & nifD, nifH & Nod- & [25] \\
\hline \multicolumn{6}{|l|}{ Cupriavidus } \\
\hline $\begin{array}{l}\text { Cupriavidus agavae ASC-9842 } \\
\left(=\mathrm{LMG} 26414^{\mathrm{T}}=\text { CIP } 110327^{\mathrm{T}}\right)\end{array}$ & Agave L. rhizosphere in northeast Mexico & GCF_004217045.1 & & L.+ & [27] \\
\hline \multicolumn{6}{|l|}{ Devosia } \\
\hline $\begin{array}{l}\text { Devosia ginsengisoli Gsoil 520 } \\
\left(=\text { KACC } 19440^{\mathrm{T}}=\mathrm{LMG} 30329^{\mathrm{T}}\right) .\end{array}$ & Ginseng cultivation soil & GCF_007859655.1 & & & [28] \\
\hline $\begin{array}{l}\text { Devosia indica IO390501 } \\
\left(\text { IO390501 }^{\mathrm{T}}=\mathrm{JCM} 32636^{\mathrm{T}}\right)\end{array}$ & Sea water sample from the Indian Ocean & GCF_003056405.1 & & & [29] \\
\hline $\begin{array}{l}\text { Devosia marina } \mathrm{L} 53-10-65^{\mathrm{T}} \\
\left(=\mathrm{MCCC} 1 \mathrm{~A} 05139^{\mathrm{T}}=\mathrm{KCTC} 72888^{\mathrm{T}}\right)\end{array}$ & Deep seawater, South China Sea & GCF_009758415.1 & & & [30] \\
\hline $\begin{array}{l}\text { Devosia subaequoris } \mathrm{HST} 3-14^{\mathrm{T}} \\
\left(=\mathrm{JCM} 14206^{\mathrm{T}}=\mathrm{KCTC} 12772^{\mathrm{T}}\right)\end{array}$ & $\begin{array}{l}\text { Beach sediment sample from Hwasun Beach } \\
\text { in Jeju, Republic of Korea }\end{array}$ & GCF_014197055.1 & & & {$[30]$} \\
\hline Georhizobium & & & & & {$[4]$} \\
\hline $\begin{array}{l}\text { Georhizobium profundi WS11 } 11^{\mathrm{T}} \\
\left(=\text { MCCC } 1 \mathrm{~K} 03498^{\mathrm{T}}=\text { KCTC } 62439^{\mathrm{T}}\right)\end{array}$ & $\begin{array}{l}\text { Deep-sea sediment sample collected from the } \\
\text { New Britain Trench }\end{array}$ & GCF_003952725.1 & & & {$[4]$} \\
\hline
\end{tabular}


Table 1. Continued

\begin{tabular}{|c|c|c|c|c|c|}
\hline $\begin{array}{l}\text { Species and nomenclatural type } \\
\text { strain }\end{array}$ & Origin & $\begin{array}{l}\text { T-strain Genome } \\
\text { NCBI assembly } \\
\text { (RefSeq) accession }\end{array}$ & $\begin{array}{l}\text { Symbiotic/ } \\
\text { pathogenic } \\
\text { genes }\end{array}$ & Planttests & Reference \\
\hline 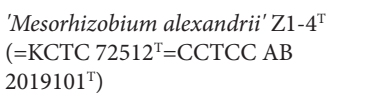 & $\begin{array}{l}\text { Phycosphere microbiota of marine } \\
\text { dinoflagellate Alexandrium minutum }\end{array}$ & GCF_004000235.1 & & & {$[31]$} \\
\hline $\begin{array}{l}\text { 'Mesorhizobium rhizophilum' YM1C- } \\
6-2^{\mathrm{T}}\left(=\text { CGMCC } 1.15487^{\mathrm{T}}=\text { DSM }\right. \\
\left.101712^{\mathrm{T}}\right)\end{array}$ & $\begin{array}{c}\text { Rhizosphere of maize grown in northeast } \\
\text { PR China }\end{array}$ & GCF_003666685.1 & & & {$[32]$} \\
\hline $\begin{array}{l}\text { Mesorhizobium terrae } \\
\text { NIBRBAC000500504 } \\
\left.72278^{\mathrm{T}}=\text { JCM } 33432^{\mathrm{T}}\right)\end{array}$ & Soil in Jangsu, Republic of Korea & GCF_008727715.1 & & & {$[33]$} \\
\hline \multicolumn{6}{|l|}{ Methylobacterium } \\
\hline 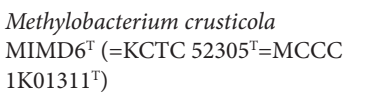 & Biological soil crusts, PR China & GCF_003574465.1 & & & [34] \\
\hline $\begin{array}{l}\text { Methylobacterium } \\
\text { nonmethylotrophicum } 6 \text { HR- } 1^{\mathrm{T}} \\
\left(=\text { GDMCC } 1.662^{\mathrm{T}}=\text { KCTC } 42760^{\mathrm{T}}\right)\end{array}$ & Tungsten mine tailings, Jiangxi, PR China & GCF_004745635.1 & & & {$[36]$} \\
\hline $\begin{array}{l}\text { Methylobacterium planium } \\
\text { YIM } 132548^{\mathrm{T}}(=\text { CGMCC } \\
\left.1.17323^{\mathrm{T}}=\text { NBRC } 114056^{\mathrm{T}}\right)\end{array}$ & $\begin{array}{l}\text { Lepraria sp. lichen collected from Yunnan, } \\
\text { southwest PR China }\end{array}$ & GCF_008806345.1 & & & {$[37]$} \\
\hline $\begin{array}{l}\text { Methylobacterium symbioticum } \\
\text { SB0023/3 }\left(=\text { CECT } 9862^{\mathrm{T}}=\text { PYCC }\right. \\
\left.8351^{\mathrm{T}}\right)\end{array}$ & $\begin{array}{c}\text { Spores of the AMF Glomus iranicum var. } \\
\text { tenuihypharum }\end{array}$ & GCF_902141845.1 & & & {$[38]$} \\
\hline $\begin{array}{l}\text { 'Methylobacterium terrae' } 17 \mathrm{Sr} 1-28^{\mathrm{T}} \\
\left(=\text { KCTC } 52904^{\mathrm{T}}=\mathrm{NBRC} 112873^{\mathrm{T}}\right)\end{array}$ & Gamma ray-irradiated soil & GCF_003173755.1 & & & {$[39,40]$} \\
\hline $\begin{array}{l}\text { 'Microvirga calopogonii' CCABU } \\
65841 \mathrm{~T} \text { (=LMG } 25488^{\mathrm{T}}=\mathrm{HAMBI} \\
\left.3033^{\mathrm{T}}\right)\end{array}$ & $\begin{array}{l}\text { Root nodule of Calopogonium mucunoides, } \\
\text { Yunan, PR China }\end{array}$ & GCF_003347665.1 & nodA, nifH & Nod- & [43] \\
\hline $\begin{array}{l}\text { 'Microvirga tunisiensis' } \text { LmiM8 }^{\mathrm{T}} \\
\left(=\text { CECT } 9163^{\mathrm{T}}=\mathrm{LMG} 29689^{\mathrm{T}}\right)\end{array}$ & $\begin{array}{l}\text { Lupinus micranthus and L. luteus grown in } \\
\text { Northern Tunisia }\end{array}$ & GCF_009296195.1 & $\operatorname{nodA}$, nifH & Yes & [44] \\
\hline Neorhizobium & & & & & \\
\hline $\begin{array}{l}\text { Neorhizobium vignae comb. } \\
\text { nov. CCBAU } 5176^{\mathrm{T}}(=\mathrm{DSM} \\
\left.25378^{\mathrm{T}}=\mathrm{HAMBI} 3039^{\mathrm{T}}\right)\end{array}$ & & GCF_000732195.1 & & & [11] \\
\hline 'Neopararhizobium' & & & & & {$[11]$} \\
\hline $\begin{array}{l}\text { 'Neopararhizobium haloflavum' } \\
\text { comb. nov. KCTC } 52582^{\mathrm{T}}(=\mathrm{MCCC} \\
\left.1 \mathrm{~K} 03228^{\mathrm{T}}=\mathrm{XC} 0140^{\mathrm{T}}\right)\end{array}$ & & GCF_002750855.1 & & & {$[11]$} \\
\hline Ochrobactrum & & & & & \\
\hline $\begin{array}{l}\text { 'Ochrobactrum soli' BO- } 7^{\mathrm{T}}(=\text { KACC } \\
\left.19676^{\mathrm{T}}=\text { LMG } 30809^{\mathrm{T}}\right)\end{array}$ & $\begin{array}{l}\text { Soil of cattle farm, in Seosan, Republic of } \\
\text { Korea }\end{array}$ & GCF_003664555.1 & & & {$[45]$} \\
\hline $\begin{array}{l}\text { Ochrobactrum teleogrylli } \mathrm{LCB8}^{\mathrm{T}} \\
\left(=\mathrm{KCTC}^{\mathrm{T}} 72031^{\mathrm{T}}=\mathrm{CGMCC}\right. \\
\left.1.13984^{\mathrm{T}}\right)\end{array}$ & $\begin{array}{l}\text { Insect Teleogryllus occipitalis, deserted } \\
\text { cropland, Shuangliu, Chengdu, PR China }\end{array}$ & GCF_006376685.1 & & & {$[46]$} \\
\hline
\end{tabular}


Table 1. Continued

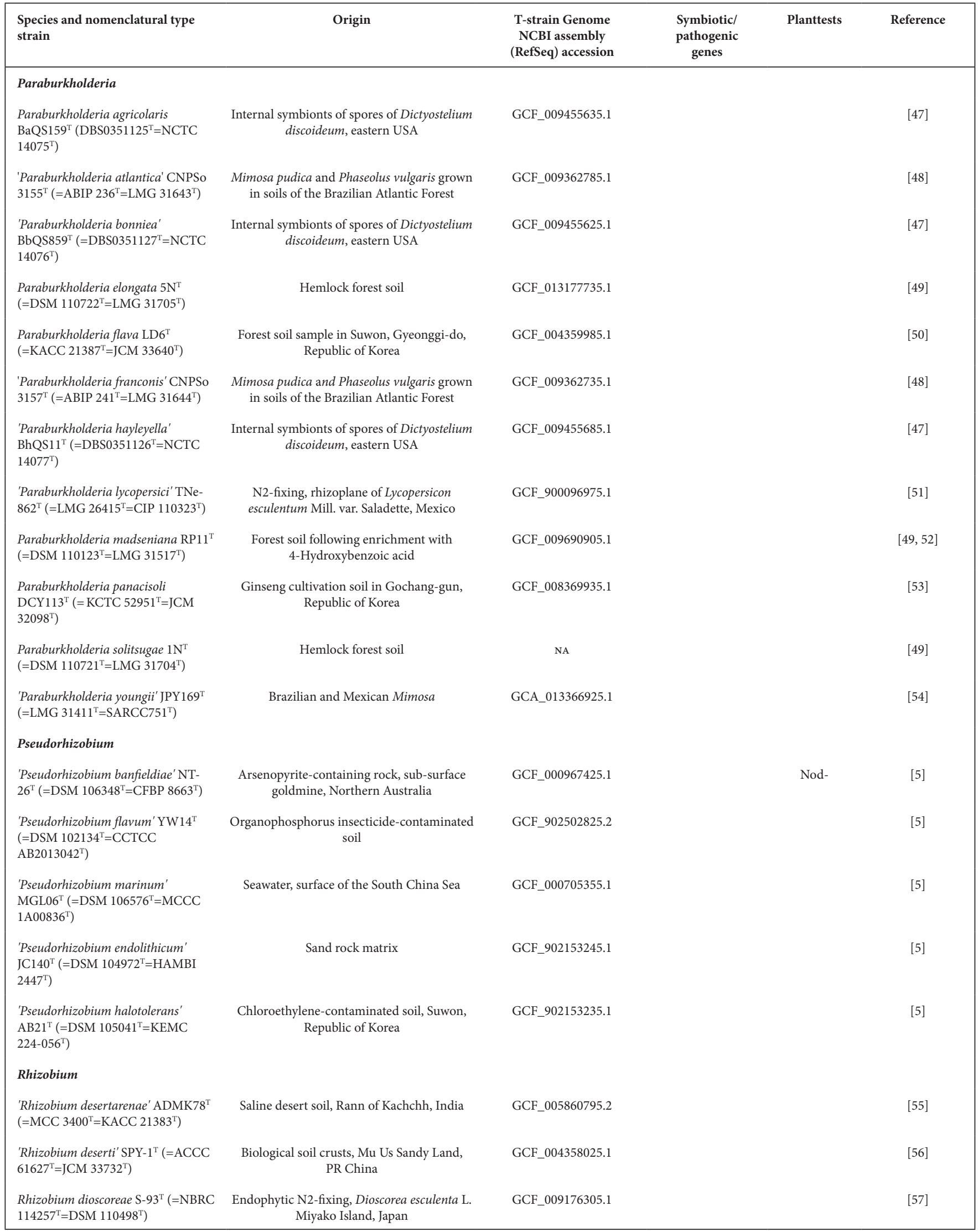


Table 1. Continued

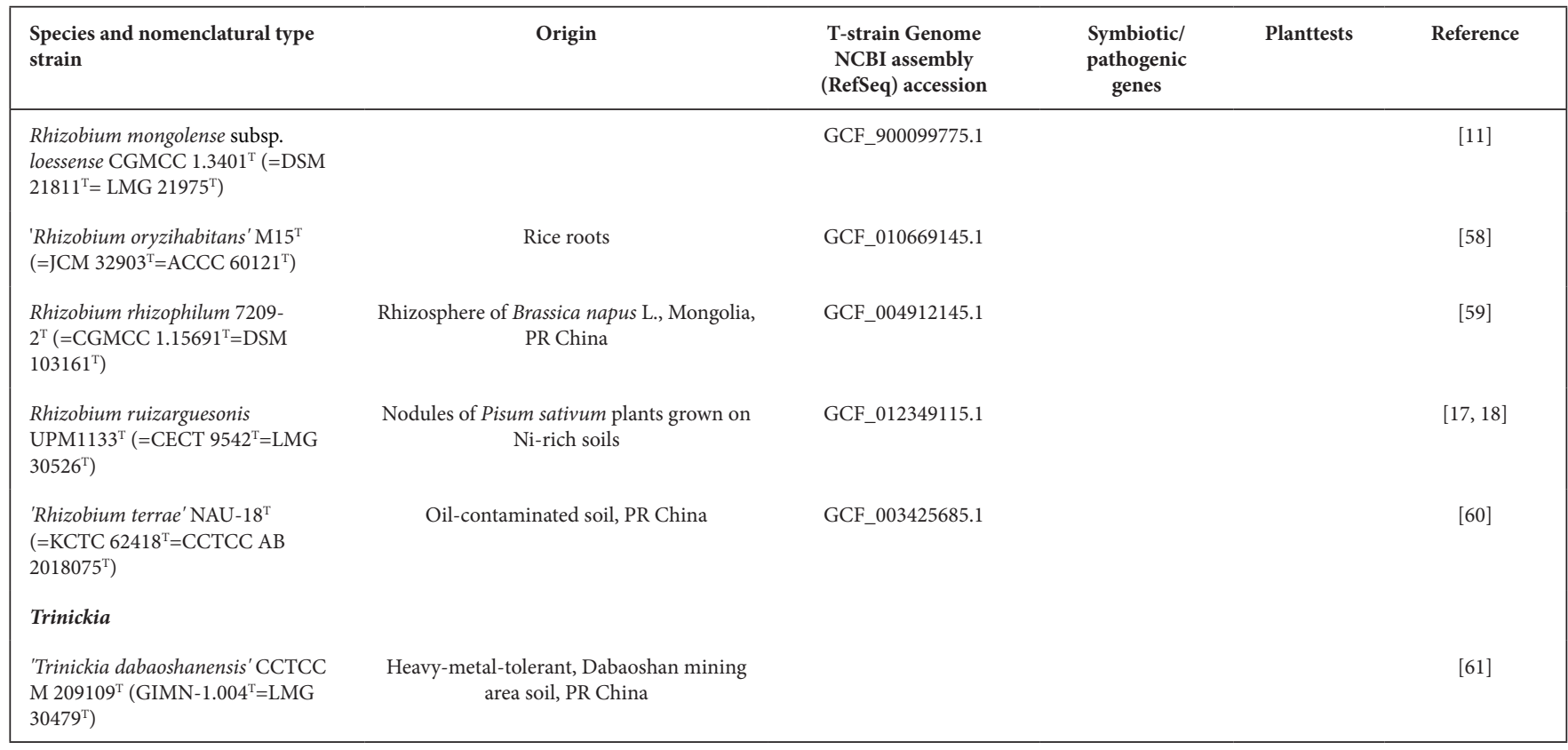

opposition among members and regular members validated these nominations by their unanimous votes. Philippe de Lajudie, as the current secretary, will inform the secretary of International Committee on Systematics of Prokaryotes (ICSP) subcommittees of this resolution. The members of the Subcommittee wish to record their gratitude to Philippe for all his hard work and devotion to the role of Secretary over the past years. He has been an excellent Secretary and has done a great deal to promote the activities of the Subcommittee.

\section{MINUTE 5. FOLLOWING UP THE PROGRESS IN RESOLUTIONS (MINUTES 6, 7, 7.1, 7.2) OF THE PREVIOUS (2019) MEETING}

5.1. As decided last year, some members edited information on Rhizobium and Pararhizobium on Wikipedia pages. All members are encouraged to contribute to maintain these general public pages as updated as possible. The Subcommittee blog (https://taxonomyagrorhizo.blogspot.com/) is now available and should also be used to increase interactions and visibility of our recommendations.

5.2. The species table hosted on the Subcommittee website (https://sites.google.com/view/taxonomyagrorhizo/), which lists type strains and links to existing genomic data cannot be maintained daily up-to-date, and this will likely become harder to do as the number of described and sequenced species grow. The LPSN (https://lpsn.dsmz.de/) and GCM (http://gcm.wdcm.org/typestrain/about.jsp) provide more up-to-date information on taxonomy and links to genomic data, so it will be more value for our effort to produce a complementary type of information. It has then been decided to turn the species table into something containing a more specialized type of information, complementary to that provided on the other sites, e.g. the interactions of rhizobia and agrobacteria with plants, including symbiotic/pathogenic aspects, host range, symbiovars/pathovars, plasmid types, etc. For agrobacterial plasmids, the new groupings proposed by Weisberg et al. [3] could be used. The recorded data would aim at reflecting the genotypic/phenotypic diversity observed within the species, rather than just metadata associated with the species type strain. A new template/frame table will be designed by a subgroup of members (L. M., F. L., R. M., S. A. M. and others) so it can later be populated by all members with relevant expertise.

\section{MINUTE 6. NEW SPECIES, SINCE THE LAST MEETING}

We commented that proposed names should attempt to best reflect the biology of the new taxa. For instance, we have doubts if, in the case of newly described genera, the suffix 'rhizobium' should be used as the root of the name when the bacterium is not present in the soil environment or is simply nonsymbiotic, like the recently proposed genus names Georhizobium [4] and Pseudorhizobium [5, 6]. Similarly, the species name Agrobacterium fabacearum was proposed for Agrobacterium genomic species G1 (5), as it has, by chance, been isolated as an endophyte in bean root nodules, but not specifically as a symbiont. In the past, Agrobacterium G1 strains were isolated from several plant types [7] and detected in soils associated with Poaceae rhizospheres [8]. The plant specificity suggested for the genomic species G1 by the name fabacearum is somehow misleading. As a matter of fact and at the same time, Velázquez et al. [9] published evidence that A. tumefaciens is the correct name for the Agrobacterium genomic species G1, solving the long-standing problem 
of confusing equivalence with $A$. radiobacter, which is the correct name for Agrobacterium G4. The name A. tumefaciens has precedence over $A$. fabacearum and thus should have priority as the valid name for Agrobacterium genomic species G1. In addition, these authors request that the type strain of A. tumefaciens be corrected from ATCC $23308^{\mathrm{T}}$ back to ATCC $4720^{\mathrm{T}}$, since the original type strain ATCC $4720^{\mathrm{T}}$ was never lost and is currently available in several culture collections. The Subcommittee supports these changes. Table 1 lists the novel taxa.

\section{MINUTE 7. RECENT RELEVANT PUBLICATIONS IN GENOME-BASED TAXONOMY}

7.1. Based on an extensive genomic and phenotypic analysis of the genus Ensifer/Sinorhizobium, Fagorzi et al. [10] concluded that it is made of two distinct clades, with inter-clade genomic similarity under $85 \%$ average nucleotide identity (ANI) and $90 \%$ average amino acid identity (AAI). They presented a large body of biological evidence suggesting that these clades harbour significantly different organisms, with one containing symbiotic strains and the other non-symbiotic strains. Conveniently, the phylogenetic boundary puts the type species and strains of Sinorhizobium and Ensifer in each of these respective clades. This indicates that the genus could be separated (again) into the genera Ensifer and Sinorhizobium, but Fagorzi et al. stop short of making a formal taxonomic proposal, although their findings are supported by several other recent reports $[5,11]$. The transfer of Sinorhizobium to Ensifer, proposed 20 years ago [12], was never accepted by the wider scientific community, as witnessed by the tenfold higher number of recent publications using the name Sinorhizobium. Resurrection of the distinction would make biological sense, as it would now separate symbiotic and non-symbiotic clades.

7.2. We discussed the report of Weisberg et al. [3], which mainly focuses on oncogenic plasmids of agrobacteria, including a large set of strains, introducing several interesting new methods of analysis, defining nine distinct plasmid groups, and having potential impacts on taxonomy of these bacteria. Advances in Ti/Ri plasmid analysis are significant, but the classification of the bacteria carrying these plasmids remains unclear. The polyphyletic group agrobacteria (tumorigenic and rhizogenic Rhizobiaceae species) is somehow considered as a taxonomic entity, without considering current evidence that biovar 2 belongs to the genus Rhizobium and biovar 3 to the genus Allorhizobium. It is clear that Ti plasmids are transmissible among several genera in the family Rhizobiaceae, even though transmission events remain rare. Known biovars of agrobacteria remain the main hosts of oncogenic plasmids, with evidence of correlation and stable coexistence between chromosomal backgrounds and Ti plasmids, likely explained by their co-evolution. In this respect it was also recently reported that Ti plasmids can be maintained in Neorhizobium species in nature [13]. In addition, Weisberg et al. [3] suggested that there is a new group of pathogenic agrobacteria that is apparently a sister species of biovar 2 . It might be similar to the species Rhizobium tumorigenes, which should be checked when sequences are available.

7.3. Following Ormeño-Orrillo et al. [14], González et al. [15] reported a robust Rhizobium phylogenomic study using ribosomal protein genes that are recommended as phylomarkers. This serves as a framework to analyse the variation profile of the Rhizobium accessory genome and provides evidence on the lateral transfer of symbiotic plasmids, as shown before for the tropici group [16]. This report confirms the misclassification of a number of strains in the NCBI previously reported by several authors.

7.4. Hördt et al. [11] reported an extensive genome-based taxonomic revision of the Alphaproteobacteria, including rhizobia and agrobacteria and extending the family Rhizobiaceae, with relevant proposals at several levels (species, genus, family, order) that will presumably be soon submitted to the International Journal of Systematic and Evolutionary Microbiology (IJSEM) for validation.

7.5. Rhizobium ruizarguesonis $[17,18]$ is within genospecies $\mathrm{C}$ of the $R$. leguminosarum species complex, so this is now the formal name for genospecies $C$. There are now five named species within the $R$. leguminosarum species complex ( $R$. leguminosarum, $R$. laguerreae, $R$. sophorae, $R$. ruizarguesonis and ' $R$. indicum') and a recent study indicates that there are more that could be named in future [19].

\section{MINUTE 8. ADJOURNMENT}

The meeting was adjourned at 13.17 UTC on 6 July 2020. As usual, it was decided to continue the meeting online until 18 December 2020.

\section{MINUTE 9. IMPACT OF THE NAGOYA PROTOCOL ON TAXONOMY}

To propose a valid description of a new species name, the type strain needs to be made available freely to the scientific community. Rule 30 [20] of the International Code of Nomenclature of Prokaryotes requires that a viable culture of that strain must be deposited in at least two publicly accessible culture collections in two different countries from which subcultures must be available with no access restriction. Changing these rules has been regularly discussed among scientists in recent years, especially regarding the acceptance of genome sequence availability in replacement of the deposition of a live bacterial culture, referring to the description of taxa not based on isolates, e.g. based on metagenome-derived sequences, which are at the moment restricted to the Candidatus status. At the origin of this requirement of type strain availability for species description is the principle that taxonomy exists to inform biology. Microbiologists should have access to described bacterial cultures, and not only to their genome sequences, to study their biological properties towards increasing knowledge in fundamental research and 
devising applications of these organisms. Yet, the difficulty remains for a number of authors to describe new species due to genetic resources access regulations in their respective countries, where, in some cases, even the genome sequence cannot be published. Public international culture collections follow the rules of the Nagoya Protocol and acknowledge the sovereign rights and legislation of the country of origin. They can only accept deposits which are obtained in respect of the laws and regulation of the country of origin. Thus, the certificate of deposit can only be issued if type strains are available without restriction, at least for research purposes. In Brazil, for instance, the law allows deposit of strains in collections abroad. However, the law requires foreign researchers to always have an official partnership with a Brazilian institution and Brazilian scientists to perform research on genetic materials from Brazil. In practice, this national regulation requires foreign researchers to sign material transfer agreements (MTAs) or other contracts with Brazilian institutions, which is already considered as a restriction on the distribution of type strains by the ICSP. In several countries, such as Algeria, strains cannot be deposited without restrictions on their distribution, which prevents any new species description in this country. This, of course, is an issue relevant to the taxonomy of all microorganisms, not specifically to those bacteria within the scope of this Subcommittee. The Subcommittee agreed that a solution to the problem needs to be worked out at the level of the national authorities whose rules and regulations are creating problems for their own researchers. It is the responsibility of the latter to explain the rules better to their national authorities and give them a better insight into the situation. If the authorities prohibit deposit of a type strain, then they should be made aware that no new bacteria from their country can be described. This is a loss for the local scientists as well as for science worldwide. If biodiversity is not described and made available beyond national borders, it will not be used and cannot lead to local benefits from use by international partners. All the documentation that public culture collections require from their customers in the framework of the Nagoya Protocol is precisely to ensure that the country of origin is acknowledged and any benefits can be equitably shared. Although in some particular situations some species can indeed be endemic to a single country, most bacterial taxa are likely to be found more widely if efforts are made to look for them. It must be emphasized that the endemic character of a species can be validated and further reinforced for the country of origin only by allowing its comparison (through its type strain) with future descriptions internationally. In the time course of this discussion, the Subcommittee became aware of a working group at the ICSP Executive Board level on type strain accessibility and MTAs attached to type strains. Soon an Editorial should be published in the IJSEM to remind readers what the purpose of a type strain is, and to make updated recommendations (ICSP Executive Board, 29 October 2020, minute 8; www. the-icsp.org/reports).

\section{MINUTE 10. CLOSING}

The online phase of this meeting was closed on 18 December 2020 .

Funding information

The authors received no specific grant from any funding agency.

Conflicts of interest

The authors declare that there are no conflicts of interest.

References

1. de Lajudie P, Young JPW. International Committee on Systematics of Prokaryotes Subcommittee on the Taxonomy of Rhizobia and Agrobacteria minutes of the closed meeting by videoconference, 17 July 2019. Int J Syst Evol Microbiol 2020;70:3563-3571.

2. Whitman WB, Bull CT, Busse H-J, Fournier P-E, Oren A et al. Request for revision of the statutes of the International Committee on Systematics of prokaryotes. Int $J$ Syst Evol Microbiol 2019;69:584-593.

3. Weisberg AJ, Davis EW, Tabima J, Belcher MS, Miller M et al. Unexpected conservation and global transmission of agrobacterial virulence plasmids. Science 2020;368:eaba5256.

4. Cao J, Wei Y, Lai Q, Wu Y, Deng J et al. Georhizobium profundi gen. nov., sp. nov., a piezotolerant bacterium isolated from a deep-sea sediment sample of the New Britain Trench. Int J Syst Evol Microbiol 2020;70:373-379

5. Lassalle F, Dastgheib SMM, Zhao F-J, Zhang J, Verbarg S et al. Phylogenomics reveals the basis of adaptation of Pseudorhizobium species to extreme environments and supports a taxonomic revision of the genus. Syst Appl Microbiol 2021;44:126165.

6. Kimes NE, López-Pérez M, Flores-Félix JD, Ramírez-Bahena M-H, Igual JM et al. Pseudorhizobium pelagicum gen. nov., sp. nov. isolated from a pelagic Mediterranean zone. Syst Appl Microbiol 2015;38:293-299.

7. Costechareyre D, Bertolla F, Nesme X. Homologous recombination in Agrobacterium: potential implications for the genomic species concept in bacteria. Mol Biol Evol 2009;26:167-176.

8. Shams M, Vial L, Chapulliot D, Nesme X, Lavire C. Rapid and accurate species and genomic species identification and exhaustive population diversity assessment of Agrobacterium spp. using recAbased PCR. Syst Appl Microbiol 2013;36:351-358.

9. Velázquez E, Flores-Félix JD, Sánchez-Juanes F, Igual JM, Peix Álvaro. Strain ATCC $4720^{\top}$ is the authentic type strain of Agrobacterium tumefaciens, which is $n^{t}$ a later heterotypic synonym of Agrobacterium radiobacter. Int J Syst Evol Microbiol 2020;70:5172-5176.

10. Fagorzi C, Ilie A, Decorosi F, Cangioli L, Viti C. Symbiotic and nonsymbiotic members of the genus Ensifer (syn. Sinorhizobium) are separated into two clades based on comparative genomics and high-throughput phenotyping. bioRxiv 2020

11. Hördt A, López MG, Meier-Kolthoff JP, Schleuning M, Weinhold L-M et al. Analysis of 1,000+ type-strain genomes substantially improves taxonomic classification of Alphaproteobacteria. Front Microbiol 2020;11:468.

12. Young JM. The genus name Ensifer Casida 1982 takes priority over Sinorhizobium Chen et al. 1988, and Sinorhizobium morelense Wang et al. 2002 is a later synonym of Ensifer adhaerens Casida 1982. Is the combination "Sinorhizobium adhaerens" (Casida 1982) Willems et al. 2003 legitimate? Request for an Opinion. Int J Syst Evol Microbiol 2003;53:2107-2110.

13. Haryono M, Tsai Y-M, Lin C-T, Huang F-C, Ye Y-C, et al. Presence of an Agrobacterium-type tumor-inducing plasmid in Neorhizobium sp. NCHU2750 and the link to phytopathogenicity. Genome Biol Evol 2018;10:3188-3195.

14. Ormeño-Orrillo E, Servín-Garcidueñas LE, Rogel MA, González V Peralta $\mathrm{H}$ et al. Taxonomy of rhizobia and agrobacteria from the Rhizobiaceae family in light of genomics. Syst Appl Microbiol 2015;38:287-291. 
15. González V, Santamaría RI, Bustos P, Pérez-Carrascal OM, Vinuesa $\mathrm{P}$ et al. Phylogenomic Rhizobium species are structured by a continuum of diversity and genomic clusters. Front Microbiol 2019;10:910.

16. Ramírez-Puebla ST, Hernández MAR, Guerrero Ruiz G, OrmeñoOrrillo E, Martinez-Romero JC et al. Nodule bacteria from the cultured legume Phaseolus dumosus (belonging to the Phaseolus vulgaris cross-inoculation group) with common tropici phenotypic characteristics and symbiovar but distinctive phylogenomic position and chromid. Syst Appl Microbiol 2019;42:373-382.

17. Jorrin B, Palacios JM, Peix Álvaro, Imperial J. Rhizobium ruizarguesonis sp. nov., isolated from nodules of Pisum sativum L. Syst Appl Microbiol 2020:43:126090.

18. Oren A, Garrity GM. Validation List no. 195. List of new names and new combinations previously effectively, but not validly, published. Int J Syst Evol Microbiol 2020;70:4844-4847.

19. Young JPW, Moeskjær S, Afonin A, Rahi P, Maluk M. Defining the Rhizobium leguminosarum species complex. Preprints 2020. Genes 2021:12:111.1.

20. Flores-Félix JD, Menéndez E, Ramírez-Bahena MH, Peix A, GarcíaFraile $\mathrm{P}$ et al. Agrobacterium cavarae sp. nov., isolated from maize (Zea mays L.) roots. Int J Syst Evol Microbiol 2020;70:5512-5519.

21. Delamuta JRM, Scherer AJ, Ribeiro RA, Hungria M. Genetic diversity of Agrobacterium species isolated from nodules of common bean and soybean in Brazil, Mexico, Ecuador and Mozambique, and description of the new species Agrobacterium fabacearum sp. nov. Int J Syst Evol Microbiol 2020;70:4233-4244.

22. Lin S-Y, Hameed A, Huang H-I, Young C-C. Allorhizobium terrae sp. nov., isolated from paddy soil, and reclassification of Rhizobium oryziradicis (Zhao et al. 2017) as Allorhizobium oryziradicis comb. nov. Int J Syst Evol Microbiol 2020;70:397-405

23. Helene LCF, Klepa MS, O'Hara G, Hungria M. Bradyrhizobium archetypum sp. nov., Bradyrhizobium australiense sp. nov. and Bradyrhizobium murdochi sp. nov., isolated from nodules of legumes indigenous to Western Australia. Int J Syst Evol Microbiol 2020;70:4623-4636.

24. Cabral Michel D, Martins da Costa E, Azarias Guimarães A, Soares de Carvalho T, Santos de Castro Caputo P et al. Bradyrhizobium campsiandrae sp. nov., a nitrogen-fixing bacterial strain isolated from a native leguminous tree from the Amazon adapted to flooded conditions. Arch Microbiol 2021;203:233-240.

25. Wasai-Hara S, Minamisawa K, Cloutier S, Bromfield ESP. Strains of Bradyrhizobium cosmicum sp. nov., isolated from contrasting habitats in Japan and Canada possess photosynthesis gene clusters with the hallmark of genomic islands. Int J Syst Evol Microbiol 2020;70:5063-5074

26. Rejili M, Off K, Brachmann A, Marín M. Bradyrhizobium hipponense sp. nov., isolated from Lupinus angustifolius growing in the northern region of Tunisia. Int J Syst Evol Microbiol 2020;70:5539-5550.

27. Arroyo-Herrera I, Maldonado-Hernández J, Rojas-Rojas F-U, Meza-Radilla G, Larios-Serrato V et al. Cupriavidus agavae sp. nov., a species isolated from Agave L. rhizosphere in northeast Mexico. Int J Syst Evol Microbiol 2020;70:4165-4170.

28. Quan X-T, Siddiqi MZ, Liu Q-Z, Lee S-M, Im W-T, . Devosia ginsengisoli sp. nov., isolated from ginseng cultivation soil. Int J Syst Evol Microbiol 2020;70:1489-1495.

29. Lin D, Huang Y, Chen Y, Zhu S, Yang J et al. Devosia indica sp. nov., isolated from surface seawater in the Indian Ocean. Int J Syst Evol Microbiol 2020;70:340-345.

30. Liu Y, Du J, Zhang J, Lai Q, Shao Z et al. Devosia marina sp. nov., isolated from deep seawater of the South China Sea, and reclassification of Devosia subaequoris as a later heterotypic synonym of Devosia soli. Int J Syst Evol Microbiol 2020;70:3062-3068.

31. Yang X, Jiang Z, Zhang J, Zhou X, Zhang X et al. Mesorhizobium alexandrii sp. nov., isolated from phycosphere microbiota of PSTsproducing marine dinoflagellate Alexandrium minutum amtk4. Antonie van Leeuwenhoek 2020;113:907-917.
32. Gao J-L, Xue J, Sun Y-C, Xue H, Wang ET et al. Mesorhizobium rhizophilum sp. nov., a 1-aminocyclopropane-1-carboxylate deaminase producing bacterium isolated from rhizosphere of maize in Northeast China. Antonie van Leeuwenhoek 2020;113:1179-1189.

33. Jung Y-J, Kim H-J, Hur M. Mesorhizobium terrae sp. nov., a novel species isolated from soil in Jangsu, Korea. Antonie van Leeuwenhoek 2020;113:1279-1287

34. Jia LJ, Zhang KS, Tang K, Meng JY, Zheng C et al. Methylobacterium crusticola sp. nov., isolated from biological soil crusts. Int J Syst Evol Microbiol 2020;70:2089-2095.

35. Kim J, Chhetri G, Kim I, Kim MK, Seo T. Methylobacterium durans $\mathrm{sp}$. nov., a radiation-resistant bacterium isolated from gamma rayirradiated soil. Antonie Van Leeuwenhoek 2020;113:211-220.

36. Feng G-D, Chen W, Zhang X-J, Zhang J, Wang S-N et al. Methylobacterium nonmethylotrophicum sp. nov., isolated from tungsten mine tailing. Int J Syst Evol Microbiol 2020;70:2867-2872.

37. Jiang L, An D, Wang X, Zhang K, Li G et al. Methylobacterium planium sp. nov., isolated from a lichen sample. Arch Microbiol 2020;202:1709-1715.

38. Pascual JA, Ros M, Martínez J, Carmona F, Bernabé A et al. Methylobacterium symbioticum sp. nov., a new species isolated from spores of Glomus iranicum var. tenuihypharum. Curr Microbiol 2020;77:2031-2041.

39. Kim J, Chhetri G, Kim I, Kim H, Kim MK et al. Methylobacterium terrae sp. nov., a radiation-resistant bacterium isolated from gamma ray-irradiated soil. J Microbiol 2019;57:959-966.

40. Kim J, Chhetri G, Kim I, Kim H, Kim MK et al. Erratum to: Methylobacterium terrae $\mathrm{sp}$. nov., a radiation-resistant bacterium isolated from gamma ray-irradiated soil. J Microbiol 2020;58:79.

41. Kim J, Chhetri G, Kim I, Lee B, Jang W et al. Methylobacterium terricola sp. nov., a gamma radiation-resistant bacterium isolated from gamma ray-irradiated soil. Int J Syst Evol Microbiol 2020;70:2449-2456.

42. Liu Z-T, Xian W-D, Li M-M, Liu L, Ming Y-Z et al. Microvirga arsenatis sp. nov., an arsenate reduction bacterium isolated from Tibet hot spring sediments. Antonie van Leeuwenhoek 2020;113:1147-1153.

43. Wang F, Yang L, Deng J, Liu X, Lu Y et al. Microvirga calopogonii sp. nov., a novel alphaproteobacterium isolated from a root nodule of Calopogonium mucunoides in Southwest China. Antonie van Leeuwenhoek 2019:112:1593-1602.

44. Msaddak A, Rejili M, Durán D, Mars M, Palacios JM et al. Microvirga tunisiensis sp. nov., a root nodule symbiotic bacterium isolated from Lupinus micranthus and L. luteus grown in Northern Tunisia. Syst Appl Microbiol 2019:42:126015.

45. Choi G-M, Kim KM, Yun C-S, Lee SY, Kim SY et al. Ochrobactrum soli sp. nov., isolated from a Korean cattle farm. Curr Microbiol 2020;77:1104-1110.

46. Hu M, Li X, Li Z, Liu B, Yang Z et al. Ochrobactrum teleogrylli sp. nov., a pesticide-degrading bacterium isolated from the insect Teleogryllus occipitalis living in deserted cropland. Int J Syst Evol Microbiol 2020;70:2217-2225.

47. Brock DA, Noh S, Hubert ANM, Haselkorn TS, DiSalvo S et al. Endosymbiotic adaptations in three new bacterial species associated with Dictyostelium discoideum: Paraburkholderia agricolaris sp. nov., Paraburkholderia hayleyella sp. nov., and Paraburkholderia bonniea sp. nov. PeerJ 2020;8:e9151.

48. Paulitsch F, Dall'Agnol RF, Delamuta JRM, Ribeiro RA, da Silva Batista JS et al. Paraburkholderia atlantica Sp. nov. and Paraburkholderia franconis sp. nov., two new nitrogen-fixing nodulating species isolated from Atlantic forest soils in Brazil. Arch Microbiol 2020;202:1369-1380

49. Wilhelm RC, Cyle KT, Martinez CE, Karasz DC, Newman JD et al. Paraburkholderia solitsugae sp. nov. and Paraburkholderia elongata sp. nov., phenolic acid-degrading bacteria isolated from forest soil and emended description of Paraburkholderia madseniana. Int $J$ Syst Evol Microbiol 2020;70:5093-5105.

50. Trinh NH, Kim J. Paraburkholderia flava sp. nov., isolated from cool temperate forest soil. Int J Syst Evol Microbiol 2020;70:2509-2514. 
51. Tapia-García EY, Arroyo-Herrera I, Rojas-Rojas FU, Ibarra JA, Vásquez-Murrieta MS et al. Paraburkholderia lycopersici sp. nov., a nitrogen-fixing species isolated from rhizoplane of Lycopersicon esculentum Mill. var. saladette in Mexico. Syst Appl Microbiol 2020;43:126133.

52. Wilhelm RC, Murphy SJL, Feriancek NM, Karasz DC, DeRito CM et al. Paraburkholderia madseniana sp. nov., a phenolic acid-degrading bacterium isolated from acidic forest soil. Int J Syst Evol Microbiol 2020;70:2137-2146.

53. Huo Y, Chokkalingam M, Kang J-P, Ahn J-C, Yang D-C. Paraburkholderia panacisoli sp. nov., a potentially antagonistic bacterium against the root rot fungal pathogen Cylindrocarpon destructans, isolated from ginseng cultivation soil. Arch Microbiol 2020;202:1341-1347.

54. Mavima L, Beukes CW, Palmer M, De Meyer SE, James EK. Paraburkholderia youngii sp. nov. and 'Paraburkholderia atlantica' - Brazilian and Mexican Mimosa-associated rhizobia that were previously known as Paraburkholderia tuberum sv. mimosae. Syst Appl Microbiol 2020;126152.

55. Khairnar M, Hagir A, Narayan A, Jain K, Madamwar D. Rhizobium desertarenae sp. nov., isolated from the saline desert soil from the Rann of Kachchh, India. bioRxiv 2020.
56. Liu L, Liang L, Xu L, Chi M, Zhang X et al. Rhizobium deserti sp. nov isolated from biological soil crusts collected at Mu Us sandy land, China. Curr Microbiol 2020;77:327-333.

57. Ouyabe M, Tanaka N, Shiwa Y, Fujita N, Kikuno H et al. Rhizobium dioscoreae sp. nov., a plant growth-promoting bacterium isolated from yam (Dioscorea species). Int J Syst Evol Microbiol 2020;70:5054-5062.

58. Zhao J, Zhao X, Wang J, Gong Q, Zhang X et al. Isolation, identification and characterization of endophytic bacterium Rhizobium oryzihabitans sp. nov., from rice root with biotechnological potential in agriculture. Microorganisms 2020;8:608.

59. Gao J-L, Wang L-W, Xue J, Tong S, Peng G et al. Rhizobium rhizophilum sp. nov., an indole acetic acid-producing bacterium isolated from rape (Brassica napus L.) rhizosphere soil. Int J Syst Evol Microbiol 2020;70:5019-5025.

60. Ruan Z-P, Cao W-M, Zhang X, Liu J-T-Y, Zhu J-C et al. Rhizobium terrae sp. nov., isolated from an oil-contaminated soil in China. Curr Microbiol 2020;77:1117-1124.

61. Estrada-de Los Santos P, Palmer M, Steenkamp ET, Maluk M, Beukes $\mathrm{C}$ et al. Trinickia dabaoshanensis sp. nov., a new name for a lost species. Arch Microbiol 2019;201:1313-1316.

\section{Five reasons to publish your next article with a Microbiology Society journal}

1. The Microbiology Society is a not-for-profit organization.

2. We offer fast and rigorous peer review - average time to first decision is 4-6 weeks.

3. Our journals have a global readership with subscriptions held in research institutions around the world.

4. $80 \%$ of our authors rate our submission process as 'excellent' or 'very good'.

5. Your article will be published on an interactive journal platform with advanced metrics.

Find out more and submit your article at microbiologyresearch.org. 